\title{
ВИЗНАЧЕННЯ ПОНЯТТЯ ТА ОСНОВНІ ФУНКЦІЇ НЕУРЯДОВИХ ПРАВОЗАХИСНИХ ОРГАНІЗАЦІЙ
}

\author{
ДЕМЦДЕНКО Анастасія Леонідівна - аспірантка кафедри конституційного \\ права України Національного юридичного університету України ім. Ярослава \\ Мудрого
}

DOI:10.32782/LAW.2020.1.6

\section{Постановка проблеми}

Українське суспільство переживає сьогодні складний період свого становлення, який можна назвати етапом політичних, економічних та соціальних змін. Передусім ідеться про обрання європейського вектора розвитку, а пріоритетом - захист прав та свобод людини і громадянина, бо саме належна реалізація й ефективний захист прав людини - це критерій визнання сучасної держави демократичною і правовою.

У той же час варто пам'ятати, що починати будь-які перетворення слід із підвищення правової культури, активізації і посилення протидії порушенням законних прав громадян з боку представників влади, що, до речі, є одним із головних завдань неурядових правозахисних організацій: саме вони покликані забезпечувати громадський контроль за діяльністю як державних органів, їх посадових осіб, так і суб'єктів приватного права, що, у свою чергу, сприяє зміцненню позицій громадянського суспільства в Україні як правовій державі.

Для повного розуміння мети діяльності таких організацій необхідно дослідити значення поняття «міжнародні неурядові правозахисні організації», 3'ясувати їх основні функції.

Теоретичною основою при вивченні окресленого питання мали праці Г. В. Берченка, I. О. Грицая, ᄉ. I. Летнянчина, В. В. Речицького, Т. М. Слінько. Крім того, проблема визначення поняття «неурядові правозахисні організації» й з'ясування їх основних функцій знаходяться в колі інтересів Харківського правозахисника С. Ю. Захарова.

Метою наукової статті $є$ дослідити i 3'ясувати поняття, ознаки і функції неурядових правозахисних організацій в Україні та світі, відокремити їх від інших інститутів громадянського суспільства задля всебічного розуміння їх діяльності та перспектив розвитку цього інституту.

\section{Виклад основного матеріалу}

Приступаючи до висвітлення питання, вкажемо, що суспільне життя Европи, особливо Східної, наприкінці XX - початку XXI століття тісно пов'язане з прискоренням багатьох процесів, що, у свою чергу, зумовило підвищення інтересу до проблеми громадянського суспільства і до забезпечення на практиці прав та свобод як окремого громадянина, так і громади в цілому. Звісно, як складова європейського простору, Україна не $\epsilon$ винятком. Зауважимо, що процес демократизації в нашій державі супроводжується розбудовою інститутів громадянського суспільства, завдяки діяльності яких формується суспільна правосвідомість і закріплюється пріоритет прав і свобод людини. Звісно, ці інститути різні за чисельністю, мають неоднакові повноваження, завдання та територіальний вплив, але їх кінцева мета та призначення - вирішення повсякденних питань та здійснення практичного самоврядування. 


\section{Теорія, історія держави і права, конституційне право}

Не можна оминути й того, що саме процеси демократизації суспільства як на національному, так і на світовому рівні зумовлюють появу у людини-громадянина розуміння та відчуття незалежності від держави, що, звісно, стимулює створення суспільних інститутів, відокремлених від державного апарату, які діють у межах громадянського суспільства.

У той же час, на переконання науковців, громадянське суспільство - це система, що характеризується наявністю трьох складових - трьох секторів, а саме: державного (першого), комерційного (другого) та недержавного (третього). Врівноважуючи суспільство, ці сектори уможливлюють нормальний розвиток особистості, оскільки без дієвого недержавного сектора існування як правової держави, так і громадянського суспільства просто неможливе [1].

Ця система виникла на противагу системі «держава», а головною причиною цього є відокремлення і відмежування життя людей від державного офіціозу, державної машини як апарату громадського адміністрування. До речі, саме це становить сутність, головну ознаку громадянського суспільства, робить його справжньою рушійною силою соціальної демократизації. Із наведеного можна зробити висновок, що громадянське суспільство - це альтернатива, контрагент державного врядування, якому властиві формалізм, ієрархія, централізована директивність й етатистські замахи. Крім того, воно не є структурною одиницею, а його слід розглядати передусім як спосіб життя людей у стилі приватності, сферу людської свободи, життедіяльність особистостей поза офіційною регламентацією, властиву кожній людині частку неказенного, цивільного у іiі житті [2]. На підтвердження попередньої тези наведемо думку В. В. Речицького, який зазначає, що існує позиція, згідно з якою громадянське суспільство й держава для конституціоналістів - це не партнери, а «органічні» антагоністи [3].

У свою чергу, «Великий енциклопедичний словник» та «Юридична енциклопедія» наводять таке визначення даного поняття: громадянське суспільство - це суспільство
3 розвиненими економічними, політичними, духовними та іншими відносинами i зв'язками, яке взаємодіє з державою і функціонує на засадах демократії і права. Побудова громадянського суспільства $є$ метою суспільного розвитку, засобом всебічного забезпечення інтересів, прав та свобод людини і громадянина [4].

Аналіз різних точок зору стосовно тлумачення поняття «громадянське суспільство» дає можливість визначити його основні особливості та зробити висновок, що воно $є$ певною системою і діє через певні елементи - власні інститути. Як зазначив Г. В. Берченко, саме формалізація громадянського суспільства в будь-які інститути є показником його зрілості і здатності більш цілеспрямовано і ефективно виражати і реалізовувати свої інтереси [5]. Ці інститути утворюються шляхом об'єднання громадян, а на думкуᄉ. I. Летнянчина, свобода об'єднання - це одне із невід'ємних прав людини, що закріплене у багатьох міжнародно-правових документах, як от Загальна декларація прав людини 1948 р. (ст. 20), Конвенція про свободу асоціації та захисту права на організацію 1948 р. (статті 2, 10), Конвенція про захист прав людини і основоположних свобод 1950 р. (ст. 11), Міжнародний пакт про громадянські та політичні права 1966 р. (ст. 22). Як і інші документи, Конституція України (ст. 36) відповідно до загальновизнаних міжнародних стандартів гарантує і захищає це право [6]. Із цього приводу Т. М. Слінько вказує, що недержавні організації як елемент громадського суспільства виконують функції посередників між державою і суспільством [7]. Неурядові правозахисні організації (далі - НПО) є однією з форм таких об'єднань та відповідно інститутів громадянського суспільства. Завдяки своїй діяльності вони виконують завдання громадянського суспільства із дотримання принципів останнього. Їх кількість та якість - це показник розвиненого недержавного сектора правозахисної системи. Ефективне правове регулювання їх діяльності надасть змогу підвищити рівень правової освіти громадян, суттєво допоможе уряду в забезпеченні законності й підготовці та втіленні соціальних та економічних програм. 
Такі організації мають певні особливості.

По-перше, НПО є основною формою організації громадянського суспільства у сфері захисту прав людини, адже саме за їх допомогою (через їх представників) громадяни залучаються до прийняття справедливих судових рішень, тобто отримують можливість впливати на судову систему.

По-друге, будучи посередником між державою і громадянами, налагоджуючи діалог та співробітництво між ними, НПО допомагають державним структурам бути краще обізнаними з сучасним станом дотримання законності у сфері прав людини, а населенню - зрозуміти політику й логіку рішень органів державної влади і, у разі необхідності, забезпечити підтримку.

По-третє, НПО, представляючи інтереси суспільства і пересічних громадян, краще обізнані з їх нагальними потребами, а також проблемами. Ними накопичено позитивний (часто альтернативний державній практиці) досвід вирішення проблем і задоволення потреб, який може бути цікавий для державних структур.

По-четверте, НПО функціонують як спостерігачі у певній сфері, оскільки добровільно беруть на себе функції «жандармів»: фіксують зміни на своїй ділянці роботи, слідкують за дотриманням правових норм, відслідковують вплив нормативно-регулятивних змін у країні, регіоні, місцевості. У разі виникнення загрози порушення прав людини вони можуть оперативно, привернувши до неї увагу громадськості, 3МI, державних структур, мобілізувати їх на конкретну діяльність.

По-п'яте, НПО представлені широкими верствами населення і різними соціальними групами 3 діаметрально протилежними інтересами. Їх залучення дозволяє прийняти найбільш справедливе рішення.

Спираючись на наведені особливості неурядових правозахисних організацій, можемо вивести їх визначення. Щоправда, при цьому варто брати до уваги загальне поняття інститутів громадянського суспільства, яке в Україні до 2007 року було більше філософською категорією, оскільки не мало законодавчо окреслених меж. Проте у листопаді 2007 р. розпорядженням Уряду № 1035-р схвалено Концепцію сприяння органами виконавчої влади розвитку громадянського суспільства, постановою Кабінету Міністрів України від 5 листопада 2008 р. №976 затверджено порядок сприяння проведенню громадської експертизи діяльності органів виконавчої влади. Згідно із зазначеними актами до інститутів громадянського суспільства віднесено також і правозахисні організації.

Незважаючи на наявність начебто спеціальних актів, законодавчо встановленого визначення терміна «неурядові правозахисні організації» й досі не наведено. Натомість Є. Ю. Захаров визначає правозахисні організації (ПО) як особливий вид недержавних неприбуткових організацій, діяльність яких спрямована на утвердження й захист прав і свобод людини, ефективний контроль за їх дотриманням державою, іiі органами і посадовими особами. ПО сприяють зменшенню організованого насильства, здійснюваного державою. Для цього вони працюють одночасно у трьох напрямках:

1) захист прав людини в конкретних випадках (ця допомога повинна бути безкоштовною для заявника), громадські розслідування фактів порушень прав людини державними органами;

2) поширення інформації про права людини, правове виховання;

3) аналіз стану з правами людини [8].

У свою чергу, I. О. Грицай дає визначення поняття «неурядові правозахисні організації» через їх особливості: 1) основна мета діяльності - захист прав та законних інтересів як фізичних, так і юридичних осіб; 2) учасниками організації можуть бути як фізичні, так і юридичні особи; 3) засновані на добровільному волевиявленні учасників організації; 4) пройшли законодавчо визначений процес легитимізації; 5) наявна внутрішня структурованість і органи самоуправління; 6) незалежні від прямого адміністративного впливу уряду та інших органів виконавчої влади; 7) засновані на недержавних коштах [9].

Узагальнивши наведені трактування, можемо дати наступне визначення: неурядова правозахисна організація - це неполітичне, офіційно зареєстроване, внутрішньо 


\section{Теорія, історія держави і права, конституційне право}

упорядковане, добровільне об'єднання фізичних та/або юридичних осіб, що діє за рахунок приватних коштів, не підпорядковане органам виконавчої влади та не наділене владними повноваженнями, діяльність якого проводиться як на безоплатній, так і на платній основі, спрямована на захист прав усіх суб'єктів.

Станом на сьогодні в Сдиному реєстрі громадських формувань третина зареєстрованих громадських організацій виконує правозахисні функції. Така ситуація свідчить про значну кількість в Україні НПО та їх важливу роль у процесі зміцнення правової культури українського суспільства, відновлення суспільної справедливості за рахунок протидії порушенням закону представниками влади.

Щоправда, порядок їх діяльності так само, як і основне визначення, не закріплені на національному, загальнодержавному рівні. Оскільки НПО створюеться як об'єднання громадян, вони мають власний, внутрішній документ, у якому і встановлюються основні напрямки їх діяльності та їх компетенція.

Як вважає Є. Ю. Захаров, що НПО покликані вирішувати наступні завдання:

по-перше, захищати права і свободи людини, закріплені в Конституції і національному законодавстві (включаючи міжнародні договори, згода на обов'язковість яких дана парламентом);

по-друге, бути джерелом інформації про права людини для народу та органів влади, підвищувати рівень освіченості в галузі прав людини, заохочувати становлення цінностей і розвиток настанов, що сприяють повазі і усвідомленню прав людини;

по-третє, аналізувати стан з правами людини у своїй країні і їі окремих регіонах [8].

Для вирішення цих завдань НПО виконують такі функції (визначимо найважливіші): у практичному аспекті - розглядають заяви фізичних та юридичних осіб про недотримання прав і свобод людини, сприяють відновленню порушених прав і свобод за допомогою погоджувальної процедури (mediation), беруть участь у судовому процесі з метою захисту, відновлення порушених прав і свобод заявника; в освітньому аспекті
- збір, підготовка і поширення інформаційних матеріалів, розробка навчальних планів, моніторинг законодавства.

На міжнародному рівні неурядові правозахисні організації у сфері просування й захисту прав людини виконували і продовжують виконувати значну кількість ролей та функцій. Незважаючи на те, що існує декілька способів їх аналізу, ми розглянемо їх у наступному аспекті.

Встановлення «порядку денного». I в попередньому, і на сучасному етапі НПО відігравали головну роль у просуванні ідеї важливості їх діяльності і передбаченні цього питання в міжнародному «порядку денному». Як вказав Кофі Анан у своєму зверненні до Форуму неурядових організацій, НПО відігравали головну роль у включенні проблеми рабства до міжнародного «порядку денного» [10]. Заслуговує на увагу діяльність двох попередників лондонської громадської організації, яка тепер називається «Антирабство: Товариство проти рабства», заснованого в 1838 році, а також Товариства захисту аборигенів, заснованого в 1837 році. Так само було і із захистом поранених на полі бою, звернення до цього питання дало поштовх опрацюванню всього корпусу гуманітарного права, що був задуманий та сформований Міжнародним комітетом Червоного Хреста, а згодом - рухом Червоного Хреста. Крім того, правозахисні організації сприяли включенню переліку прав людини та механізму їх захисту до Статуту Організації Об'єднаних Націй.

Розробка законодавства. Під час переговорів 1994 - 1996 рр. у робочій групі відкритого типу, створеній для перегляду резолюції 1296 ECOSOC (XLIV), яка регламентувала співвідношення НПО та Організації Об'єднаних Націй. Деякі уряди намагалися зрозуміти різницю між представниками уряду та представниками НПО задля усвідомлення напрямків їх діяльності. 3 огляду на це, вони наполягали на дотриманні принципу, що, хоча НПО мають право робити заяви, поширювати повідомлення відповідно до встановлених процедур, «вони не можуть брати участі у переговорах». На думку цих урядів: «Прийняття рішень - це право, яке належить лише державам-членам» (резолю- 
ція ЕКОСОС 1996/31, п. 50 - перегляд резолюції 1296 (XLIV)) [11]. 3 правової точки зору наведене можна вважати правильним. Проте в останні роки НПО відіграють важливу роль у розробці міжнародних договорів та/або декларацій, а також в опрацюванні програми дій на світових конференціях 1990-х. Зокрема, Канадський уряд, пояснюючи свою позицію щодо цієї резолюції, зазначив: «Положення в пункті 50 стосується лише прямих міждержавних переговорів. НПО можуть і повинні сприяти переговорам, це положення ні в якому разі не слід тлумачити як більш обмежувальне, ніж привілейоване» [12].

Виявлення фактів та аналіз. Мабуть, найважливішою функцією, яку виконують НПО у захисті та просуванні прав людини, є збирання, оцінювання й поширення інформації. Так, виявлення фактів порушення прав людини міждержавними організаціями за останні десятиліття досить різко зросло - сьогодні це понад 30 тематичних та географічних механізмів Комісії з прав людини (спеціальних доповідачів, спеціальних представників, незалежних експертів чи робочих груп), шість договірних органів, які регулярно переглядають звіти держав-учасниць, а також, на місцях, офіси Верховного комісара $з$ прав людини в більш ніж 20 країнах. Виходячи з цього, стає зрозуміло, що міждержавний механізм захисту прав людини зупиниться, якщо його не будуть «годувати», «підживлювати» встановлені факти правозахисних неурядових організацій. Дієго Гарсія-Саян висловив це так: «Робоча група ООН з примусових зникнень разом 3 багатьма міжурядовими організаціями в основному покладається на НПО, а не на самі уряди. НПО надають Групі інформацію, тиснуть на неї та вимагають результатів. Це стосується всіх спеціалізованих груп $\mathrm{OOH}$ » $[13]$.

Свідчення, донос або мобілізачія сорому. Iснує безліч тактик, які можна застосовувати в різних ситуаціях: видання прес-релізів та проведення прес-кампаній; публікація звітів та їх поширення, особливо серед політиків; використання релігійної мережі для «свідчення»; проведення демонстрацій, мітингів; організація народних трибуналів, на яких свідки розповідають про порушення; доноси через відео, фільми, популярну музику чи театр; свідчення перед урядовими або міждержавними органами; використання факс-мереж; і останнє, використання електронної пошти та всесвітньої павутини для поширення інформації в усьому світі.

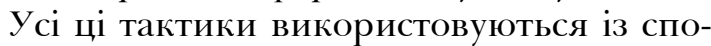
діваннями на те, що, піддаючи порушення жорстокій критиці, викладеній в громадській думці, можна досягти однієї з декількох цілей: уряд може припиняти порушення; внутрішня опозиція може бути використана для дестабілізації режиму, що порушує права; та/або міжнародна опозиція може призвести до тиску та, можливо, відкритих санкцій проти уряду, що порушує право.

Міжнародна солідарність та підтримка правозахисників. Передусім наголосимо, що нині розроблена стратегія міжнародної солідарності й гуманітарної допомоги для забезпечення захисту жертв та потенційних жертв в умовах репресивних режимів, особливо захист прав людини, які перебувають під загрозою на передових лініях боротьби за права людини. Вона включає широкий спектр тактик. Розглянемо деякі 3 них. Однією є тактика «усиновлення» Amnesty International, яка стосується груп Amnesty International, які обирають конкретних політичних в'язнів і проводять агітацію за їх звільнення, іноді роками. Друга - «Мережа термінових дій», також запроваджена Amnesty, i зараз широко використовується багатьма НПО (включаючи церкви, профспілки та професійні асоціації), які організовують сотні людей у всьому світі, готові негайно реагувати (електронною поштою чи факсом) із метою запобігання катуванню, зникненню, застосуванню смертної кари та, останнім часом, насильства над жінками. Деякі спеціальні доповідачі Організації Об'єднаних Націй вживають заходів, спираючись на ці об'єднання, негайно звертаючись до уряду для запиту інформації про цю справу. Третя тактика - «супровід», розроблена Міжнародними бригадами миру для вирішення особливо небезпечних ситуацій. Остання передбачає надання цілодобової «охорони тіла» правозахисникам у зоні ризику у формі закордонного супутни- 


\section{Теорія, історія держави і права, конституційне право}

ка, озброєного лише камерою, яка, так би мовити, живе із захисником і всюди їздить 3 ним. Піонером у цьому стали Сальвадор та Шрі-Аанка, в яких обгрунтовано передумову таких дій. Завдяки цьому влада (військова, воєнізована чи цивільна) має менше змоги вбити чи викрасти активіста, бо існує такий міжнародний контроль.

Oсвіта. Шоста функція, що набула особливої актуальності для суспільств, які переходять від авторитарного чи диктаторського до демократичного правління. У той же час вона важлива для всіх суспільств, оскільки йдеться про освіту з прав людини. Особи і громади не можуть адекватно захищати свої права, якщо вони їх не знають. Більше того, особи, які займають владні посади, зокрема, в армії, поліції, а також урядові чиновники та парламентарі, повинні знати, що існують обмеження в їх владі, внаслідок цього - не можуть зловживати своїми повноваженнями, спираючись на становище, «визначене» суспільством. Крім того, на наш погляд, варто постійно нагадувати суддям та адвокатам про права людини, щоб система правосуддя керувалася у своїй діяльності верховенством закону. Звісно, це завдання покладається на НПО.

Дотримання приниипу відкритості політичної системи. Ще однією функцією, яку виконують НПО у просуванні й захисті прав ^юдини, є та, яку часто не обговорюють, але яка вважається критичною, а саме: НПО підтримують політичну систему відкритою для інших елементів громадянського суспільства. Відстоюючи свободу асоціацій, свободу думок, свободу вираження поглядів і свободу зібрань, громадські організації дають можливість громадянському суспільству функціонувати; вони створюють політичний простір для демократичних сил і, відповідно, для демократії.

\section{Висновки}

Отже, стан громадянського суспільства в державі прямо пропорційно залежить від рівня наявної демократії, яка, у свою чергу, підтримується завдяки діяльності різних елементів громадянського суспільства. Неурядові правозахисні організації є обов'язковим та найбільш дієвим складни- ком громадянського суспільства. На жаль, законодавством і досі не надано конкретного визначення НПО, але його можна визначити через їх особливості, які відрізняють ці організації від інших об'єднань громадян: неурядові правозахисні організації $є$ посередниками між суспільством та органами державної влади; мають ширшу обізнаність із проблемних питань у сфері прав людини; виступають певними спостерігачами за діяльністю структур у сфері забезпечення прав людини; складаються із різних верств населення. Ці особливості також дозволяють зрозуміти функції НПО: правозахисна, освітня, рекомендаційна (щодо нормативних актів), аналітична. I хоча, як уже зазначалося, чіткого і загальноприйнятого визначення поняття «неурядові правозахисні організації» не розроблено, та це не заважає їм відігравати важливу роль у сфері захисту прав людини. I як вважає Г. В. Берченко, неінституціоналізовану масову активність включати до структури громадянського суспільства не слід, громадянське суспільство це насамперед інститути [5]. Розгалуженість компетенції неурядових правозахисних організацій і багатоманітність функцій дозволяють найбільш широко зрозуміти стан дотримання прав людини у державі, виявити порушення, швидко і дієво відреагувати на дії з боку урядів чи інших суб'єктів чи то державної влади, чи то суспільства в цілому.

НПО повинні бути спроможними і здатними протистояти спонуканням і спокусам влади, забезпечуючи при цьому адекватні ресурси для виконання визначених вище функцій.

\section{Література}

1. Новак В. Неурядові організації або соціальне партнерство між державою і громадянським суспільством: зарубіжний досвід. Вісник НАДУП. 2005. № 1. С. 359 - 364.

2. Людина у сфері гуманітарного пізнання. Київ: Український Центр духовної культури, 1998. 408 с.

3. Конституційне А Б В. Всеволод Речицький. Харків: ТОВ «Видавництво „Права людини“», 2016. 408 с. 
4. Великий енциклопедичний юридичний словник/ за ред. Ю.С. Шемшученка. Київ, 2007. 992с.

5. Берченко Г. В. Громадянське суспільство в Україні: конституційні аспекти : монографія - Харків : Юрайт, 2014. 208 с.

6. Летнянчин $\lambda$. Проблеми конституціоналізації свободи обєднань в Україні. Вісник Національної академії правових наук України. 2014. №4. С. 65 - 75.

7. Слінько Т. М., Кушніренко О. Г. / Конституційно-правовий статус об'єднань громадян в Україні : навч. Посібник. Харків: Арсіс, 1998. 176 с.

8. Завдання, функції, права і принципи діяльності парвозахисних організацій. Що таке правозахист?; Веб-ресурс. URL: http:// khpg.org/index.php?id = 1084630553

9. Грицай I.O. Неурядові правозахисні організації як інститут громадянського суспільства. Право і суспільство. 2001. №5. C. $31-35$.
10. "Secretary-General calls partnership of NGOs, private sector, international organizations and governments powerful partnership for future", Text of remarks made by United Nations Secretary-General Kofi Annan at the non-governmental organization (NGO) 'Forum on Global Issues’, Berlin, 29 April 1999, Press Release SG/SM/6973.

11. Karin Ryan and Laurie Wiseberg, "ECOSOC resolution 1996/31: the end result of the ECOSOC Review Process of Rules Governing NGO Relations with the United Nations", in Carter Center Report, op.cit., pp. 9-24. p. 11 .

12. "Resolution 1296 revised ...", op.cit.,

13. Diego Garcia-Sayan, "Non-governmental organizations and the human rights movement in Latin America", Bulletin of Human Rights. N $^{\circ}$ 90/1, 1991, New York, NY, United Nations), pp. 31-41 at pp. 38-39. 